\title{
LA INVESTIGACIÓN DURANTE EL GRADO: ¿DÓNDE ESTAMOS?
}

\section{Jorge VILLALBA-ARIAS ${ }^{1}$.}

${ }^{1}$ Encargado de Cátedra de Psiquiatría, Facultad de Ciencias Médicas, Universidad Nacional de Asunción, Filial Santa Rosa del Aguaray. Editor Asociado, Revista Medicina Clínica y Social, Santa Rosa del Aguaray - Paraguay.

Cómo citar este artículo: Villalba-Arias J. La investigación durante el grado: ¿dónde estamos? Medicina Clínica y Social. 2018;2(1):51-53.

Por medio de la investigación científica y tecnológica se busca interpretar y dar explicación a los fenómenos de la realidad. La ciencia permite someter estas interpretaciones a comprobación mediante una sistematización para lograr objetividad en las relaciones que se establecen en dichas comprobaciones (1).

Así también, la investigación científica constituye uno de los tres pilares sobre los que se sustenta toda universidad; la nuestra no es la excepción cuando hablamos de ideologías, pero en la práctica esto cambia un poco (2).

Actualmente la Facultad de Ciencias Médicas de la Universidad Nacional de Asunción (FCM UNA), se encuentra en plena transición entre las mallas curriculares del 2011 y el 2015. Si bien ambas tienen en cuenta a la investigación dentro de sí mismas, el enfoque es algo distinto. En la malla 2011 los conocimientos necesarios para la investigación se desarrollan solo en el primer año en la asignatura Bioestadística. Otras asignaturas también realizan talleres y o seminarios sobre metodología de la investigación, pero considerando la producción científica de los estudiantes, los conocimientos ofertados son claramente insuficientes.

Es probable que, tratando de subsanar dicha cuestión, que la malla curricular 2015 desglosase los módulos pertinentes a la investigación científica y los distribuyera a lo largo de los primeros 6 semestres. Si bien esto tiene como virtud el hecho de que, en teoría, los estudiantes deberían tener acceso a un bagaje académico del tema bastante mayor, la contraparte es que los estudiantes no estarán listos para sus primeras investigaciones científicas sino después de haber vivido ya más de la mitad de su carrera universitaria (3).

A las dificultades propias de la formación que mencioné anteriormente debemos agregar la baja promoción de la investigación en muchas de las Cátedras de la FCM - UNA; las asignaturas básicas y pre - clínicas se centran mucho en el desarrollo del plan académico mientras que las clínicas se abocan primordialmente a las prácticas de los conocimientos que le son pertinentes a sus asignaturas. Esto lo hacen en detrimento de las actividades de Extensión Universitaria (EU), que por sobre todo tienen como función la de acercar al médico a su comunidad y con ello dar mayor sentido de realidad a todo aquello aprendido dentro de las paredes de la facultad. La EU también fomenta la empatía, elemento integral de la Relación Médico - Paciente que muchos estudios demuestran que es un elemento predictor del pronóstico y la adherencia terapéutica $(4,5)$. 
Igual comprometimiento sufre la investigación durante el grado y, debido a ello, si bien se puede considerar buena la producción científica en números, esto no se acompaña de un gran impacto o relevancia de los productos derivados de la investigación científica de grado. En mi opinión esto se da debido a que, como docentes, estamos fracasando en trasmitir la relevancia de la investigación científica como pilar fundamental de las Universidades. Los alumnos, en su mayoría, realizan trabajos de investigación solo para ganar puntos extras en sus asignaturas, por ende, los beneficios que puedan aportar sus investigaciones a la Universidad y al medio donde la misma se encuentra, se tornan secundarios.

En otros países de la región, hay una sostenida disminución del presupuesto orientado a las universidades públicas $y$, hay una tendencia creciente a la evaluación de resultados como orientación para el diseño de las políticas presupuestarias futuras y la concursabilidad de los recursos estatales sobre la base de esquemas competitivos tanto en el campo de la investigación como de la extensión universitaria. En otras palabras, el presupuesto de las facultades públicas es dado en proporción a su producción científica y al impacto que generan sus actividades de EU (6).

Mientras las autoridades de la FCM - UNA se sigan centrando en cuestiones asistenciales más que académicas y de investigación, nuestro ranking entre las universidades a nivel mundial seguirá muy distante de la cúspide y la excelencia y, peor aún, nuestros estudiantes seguirán careciendo del conocimiento necesario para comprender la trascendencia de la investigación científica. El enfoque asistencial ayuda a mejorar la salud de los pacientes intervenidos, pero poco o nada hace con respecto a la salud pública en general, ya sea en los aspectos de prevención o de predicción. La FCM - UNA hace historia día a día con los milagros que genera a través de sus limitados recursos económicos. Pero tiene el potencial de dejar una marca mucho mayor en tiempo y espacio si deriva más recursos a la investigación $(7,8)$.

Un buen investigador no nace durante la residencia o durante el ejercicio de la docencia. Nace en el grado. Y nuestra facultad goza del privilegio de tener a las mentes más brillantes de cada generación entre sus filas de estudiantes; es obligación de nosotros (los docentes), el asegurarnos de que dichas lumbreras exploren y exploten todo su potencial y lo enfoquen, no solo en la adquisición de nuevos conocimientos, sino también en la generación de estos.

\section{CONFLICTOS DE INTERÉS Y FUENTE DE FINANCIACIÓN}

El autor declara no poseer conflictos de interés. Fuente de financiación: ninguna.

\section{REFERENCIAS BIBLIOGRÁFICAS}

1. Buitrago Reyes LJ. La investigación científica en los estudiantes de grado y posgrado. Revista Portal de la Ciencia 2016;11.3-15. URL.

2. Figueredo-Thiel SJ. La publicación científica en la Facultad de Ciencias Médicas de la Universidad Nacional de Asunción. An. Fac. Cienc. Méd (Asunción). 2011;44(1):9-14. URL.

3. Universidad Nacional de Asunción. Acta No 19 (A.S. No 19/31/09t20161. Resolución No 0527-00-2016 del CSU de la UNA: "Por la cual se homologan el Plan Académico de la carrera de Medicina 2015; el Reglamento General de Estudios de la carrera de Medicina 2015; y el Reglamento General del Rotatorio Clínico Preprofesional Supervisado 
de la Carrera de Medicina - Malla Curricular 2015, de la Facultad de Ciencias Médicas". San Lorenzo: Universidad Nacional de Asunción; 2016. URL.

4. Kaplún G. La integralidad como movimiento instituyente en la universidad. InterCambios 2014;1(1):45-51.URL.

5. Gérvas J. Hospitalizaciones evitables en España: el poderoso atractivo del hospital y la debilidad de la atención primaria. Atlas de Variaciones en la Práctica Médica. 2011;8(4):329-330. URL.

6. Artiles Visbal L. La investigación científica y el posgrado como elementos sustentables de la universidad pública. Rev Cubana Invest Bioméd 1997;16(1):7-9. URL.

7. Top Universities [sede Web]. London. QS Top Universities; 2018 [acceso 10 de junio de 2018]. QS World University Rankings. Disponible en: https://www.topuniversities.com/university-rankings/world-university-rankings/2018

8. Vidal Layseca C. Apuntes de una vida dedicada a la gente. Lima: SINCO Editores; 2004. 


\section{RESEARCH DURING THE UNDERGRADUATE PROGRAM: WHERE ARE WE?}

\section{Jorge VILLALBA-ARIAS ${ }^{1}$.}

${ }^{1}$ Head, Psychiatry Department, School of Medical Sciences, National University of Asunción, Santa Rosa del Aguaray Campus. Associate Editor, Medicina Clínica y Social Journal, Santa Rosa del Aguaray - Paraguay.

How to cite this article: Villalba-Arias J. Research during undergraduate: Where are we? Medicina Clínica y Social. 2018;2(2):51-53.

Through scientific and technological research, we seek to interpret and explain the phenomena of reality. Science allows these interpretations to be tested by means of a systematization to achieve objectivity in the relationships established in these verifications (1).

Also, scientific research is one of the three pillars on which every university is based; ours is not the exception when we talk about ideologies but, in practice, this changes a bit (2).

Currently, the School of Medical Sciences of the National University of Asunción (FCM - UNA), is in full transition between the curricular plans of 2011 and 2015. While both take research into account, they focus on different aspects. In the 2011 curriculum, the necessary knowledge for research is developed only in the first year in the course of Biostatistics. Other subjects also hold workshops and seminars on research methodology but, considering the scientific production of the students, the knowledge offered is clearly insufficient.

It is probable that, trying to correct this question, the 2015 curricular plan would break down the modules relevant to scientific research and distribute them throughout the first six semesters. While this has as a virtue the fact that, in theory, students should have access to a more larger pool of knowledge of the subject, the counterpart is that students will only be ready for their first scientific investigations in the second half of their university career (3).

To the difficulties of the training that I mentioned above we must add the lack of encouragement of research in many of the Departments of the FCM - UNA; the basic and pre-clinical subjects are very focused on the development of the academic plan while the clinical subjects focus primarily on the knowledge practices that are relevant to their subjects. This is done to the detriment of the activities of University Outreach (EU) which, above all, have the function of bringing physicians to their communities and thereby give them a greater sense of reality to everything learned within the walls of the school. The EU also promotes empathy, an integral element of the Patient - Doctor Relationship that many studies shows is a predictor of good prognosis and therapeutic adherence $(4,5)$.

Research during school is equally affected. If we look at the numbers, the scientific production could be considered acceptable, but the results of the research do not carry great impact or relevance. In my opinion, this is due to the fact that, as teachers, we are failing to transmit the 
relevance of scientific research as a fundamental pillar of the Universities. Students mostly perform research only to earn extra points in their subjects, therefore, the benefits that their research can bring to the University and the environment around it become secondary.

In other countries of the region, there is a sustained decrease in the budget oriented to public universities, and there is a growing trend towards the evaluation of results as a guide for the design of future budgetary policies and the concurrency of state resources on the basis of competitive schemes both in the field of research and university extension. In other words, the budget of the public faculties is given in proportion to their scientific production and the impact generated by their EU activities (6).

While the authorities of the FCM - UNA continue to focus on assistance issues rather than academic and research, our ranking among universities worldwide will remain very distant from the top and excellence and, worse, our students will still lack the necessary knowledge to understand the importance of scientific research. The healthcare approach helps improve the health of the patients who undergo surgery, but little or nothing is done with respect to public health in general, either in the aspects of prevention or prediction. The FCM - UNA makes history day by day with the miracles it generates despite its limited economic resources. But it has the potential to leave a much greater mark in time and space if it derives more resources to research $(7,8)$.

A good researcher is not born during the residency or during the teaching exercise. it's born in undergraduate and graduate school. And our School enjoys the privilege of having the brightest minds of each generation among its ranks of students; It is our obligation as teachers to ensure that these luminaries explore and exploit their full potential and focus not only on the acquisition of new knowledge, but also on the generation of these.

\section{CONFLICTS OF INTEREST AND FUNDING}

Conflicts of interest: none. Funding source: none.

\section{REFERENCES}

1. Buitrago Reyes LJ. La investigación científica en los estudiantes de grado y posgrado. Revista Portal de la Ciencia 2016;11.3-15. URL.

2. Figueredo-Thiel SJ. La publicación científica en la Facultad de Ciencias Médicas de la Universidad Nacional de Asunción. An. Fac. Cienc. Méd (Asunción). 2011;44(1):9-14. $\underline{U R L}$.

3. Universidad Nacional de Asunción. Acta No 19 (A.S. No 19/31/09t20161. Resolución No 0527-00-2016 del CSU de la UNA: "Por la cual se homologan el Plan Académico de la carrera de Medicina 2015; el Reglamento General de Estudios de la carrera de Medicina 2015; y el Reglamento General del Rotatorio Clínico Preprofesional Supervisado de la Carrera de Medicina - Malla Curricular 2015, de la Facultad de Ciencias Médicas". San Lorenzo: Universidad Nacional de Asunción; 2016. URL.

4. Kaplún G. La integralidad como movimiento instituyente en la universidad. InterCambios 2014;1(1):45-51.URL. 
5. Gérvas J. Hospitalizaciones evitables en España: el poderoso atractivo del hospital y la debilidad de la atención primaria. Atlas de Variaciones en la Práctica Médica. 2011;8(4):329-330. URL.

6. Artiles Visbal L. La investigación científica y el posgrado como elementos sustentables de la universidad pública. Rev Cubana Invest Bioméd 1997;16(1):7-9. URL.

7. Top Universities [sede Web]. London. QS Top Universities; 2018 [acceso 10 de junio de 2018]. QS World University Rankings. Disponible en: https://www.topuniversities.com/university-rankings/world-university-rankings/2018

8. Vidal Layseca C. Apuntes de una vida dedicada a la gente. Lima: SINCO Editores; 2004. 